\title{
KARAKTERISTIK NORI DARI CAMPURAN RUMPUT LAUT UIva lactuca DAN Eucheuma cottonii
}

\section{Characteristics of the Nori from Mixture of Ulva lactuca and Eucheuma cottonii Seaweeds}

\author{
Fransiska Rungkat Zakaria1 ${ }^{*}$, Bambang Pontjo Priosoeryanto ${ }^{2}$, Erniati ${ }^{3}$, dan Sajida ${ }^{1}$ \\ ${ }^{1}$ Departemen IImu dan Teknologi Pangan, Fakultas Teknologi Pertanian, Institut Pertanian Bogor, Bogor, Indonesia \\ 2 Departemen Klinik Reproduksi \& Patologi Fakultas Kedokteran Hewan, Institut Pertanian Bogor, Bogor, Indonesia \\ ${ }^{3}$ Fakultas Pertanian, Universitas Malikussaleh, Lhokseumawe, Indonesia dan Prodi IImu Pangan PPs, \\ * Korespondensi Penulis: fransiskarz@gmail.com
}

Diterima: 19 Januari 2017; Disetujui: 10 April 2017

\begin{abstract}
ABSTRAK
Rumput laut jenis Ulva lactuca dan Eucheuma cottonii merupakan rumput laut yang dapat dijumpai di perairan Indonesia, akan tetapi pemanfaatannya sebagai produk nori belum dilakukan. Penelitian ini bertujuan untuk memproduksi nori dari rumput laut $U$. lactuca dan $E$. cottonii dan menguji karakteristik mutu fisik, kimia dan sensori. Dari hasil penelitian didapatkan bahwa campuran rumput laut $U$. lactuta dan $E$. cottonii dapat menghasilkan produk nori yang berkualitas. Hasil uji organoleptik menunjukkan produk nori yang dipanggang lebih dapat diterima dibandingkan nori tidak dipanggang. Karakteristik kimia dan fisik produk berbeda nyata pada taraf $5 \%$. Hasil analisis karakteristik kimia menunjukkan bahwa produk nori rumput laut $U$. lactuca dan E. cottonii mempunyai kandungan protein yang lebih rendah (18.84\%), kandungan karbohidrat yang lebih tinggi $(62.31 \%)$, kandungan serat pangan yang lebih tinggi $(36.76 \%)$ dan kapasitas antioksidan yang lebih rendah (43.01\%) dibandingkan nori komersial (karbohidrat $41.8 \%$, protein $40 \%$, serat $21.3 \%$, kapasitas antioksidan $51 \%$ ).
\end{abstract}

KATA KUNCI : nori, rumput Laut, Ulva lactuca, Eucheuma cottonii

\section{ABSTRACT}

Ulva lactuca and Eucheuma cottonii are seaweed that are available in Indonesia, but their utilization as food product is very limited. This study aimed to produce nori processed from mixture of $\underline{U}$. lactuca and $\underline{E}$. cottonii seaweed and evaluate the quality characteristics of the physical, chemical and sensory of the product. The results showed that a mixture of $\underline{U}$. lactuca and $\underline{E}$. cottonii seaweed could be processed into the nori. Organoleptic tests showed that roasted nori product were more acceptable than unroasted nori. The chemical and physical characteristics of the product significantly different at the level of 5\%. Chemical characteristics showed that the nori product from U. lactuca and E. cottonii seaweed contained higher carbohydrate (62.31\%), lower protein (18.84\%), higher fiber content (36.76\%) and slightly lower antioxidant capacity (43.01\%) compared to commercial nori (carbohydrate $41.8 \%$, protein $40 \%$, fiber $21.3 \%$, and antioxidant capacity $51 \%)$.

KEYWORDS: seaweed, nori, Ulva lactuca, Eucheuma cottonii

\section{PENDAHULUAN}

Rumput laut atau alga laut (seaweed) merupakan salah satu komoditas utama perikanan budidaya di Indonesia. Produksi rumput laut Indonesia dari tahun 2009-2014 mengalami peningkatan rata-rata 27,88\% setiap tahunnya. Pada tahun 2014, Indonesia merupakan produsen rumput laut terbesar di dunia untuk jenis Eucheuma cottonii (Ditjen Perikanan Budidaya KKP, 2014).
Rumput laut di Indonesia saat ini digunakan sebagai penghasil agar, karaginan, dan alginat yang merupakan bahan baku penting dalam industri pangan maupun non pangan. Rumput laut Eucheuma cottonii yang banyak dibudidayakan di Indonesia dimanfaatkan untuk industri penghasil karaginan dan untuk produk pangan lainnya seperti untuk campuran es, dodol dan lain-lain. Rumput laut Ulva lactuca merupakan rumput laut yang tumbuh secara alami di perairan Indonesia, di mana pemanfaatannya masih sangat terbatas. 
Pengolahan rumput laut jenis $U$. lactuca dan $E$. cottonii menjadi produk pangan seperti produk nori belum umum dilakukan. Di Indonesia, nori dibutuhkan terutama di restoran yang menyajikan makanan Jepang, Korea dan China dan diimpor langsung dari negara tersebut. Produk nori sebagai makanan ringan yang beredar di Indonesia diimpor dari Korea, China dan Thailand. Pengembangan produk nori dari rumput laut Indonesia perlu dilakukan mengingat ketersediaan rumput laut di Indonesia yang berlimpah namun belum dilakukan pengolahan secara maksimal. Selain itu produk nori rumput laut merupakan salah satu diet sehat karena mengandung serat dan komponen bioaktif sehingga memberikan manfaat untuk kesehatan. Zakaria (2015) menyatakan bahwa diet sehat merupakan kumpulan pangan sehat yang masih membawa zat gizi, serat dan komponen bioaktif yang cukup untuk pemeliharaan kesehatan tubuh.

Penelitian ini bertujuan untuk memproduksi nori dari rumput laut $U$. lactuca dan $E$. cottonii dan menguji karakteristik fisik, kimia dan sensori. Diharapkan produk nori ini dapat menjadi alternatif penyediaan produk pangan sehat bagi masyarakat. Di samping itu adanya produk nori dari rumput laut Indonesia ini diharapkan dapat menekan jumlah impor nori dari negara lain dan meningkatkan nilai jual rumput laut Indonesia khususnya jenis Ulva lactuca dan Eucheuma cottonii.

\section{BAHAN DAN METODE}

\section{Bahan dan Peralatan}

Rumput laut $E$. cottonii kering yang digunakan diperoleh dari petani rumput laut di Kecamatan Kaseman Kota Serang Provinsi Banten, sedangkan $U$. lactuca kering diperoleh dari pengumpul rumput laut di Pantai Sayang Heulang Kecamatan Pameungpeuk, Garut Jawa Barat. Peralatan yang digunakan untuk membuat nori pada penelitian ini meliputi neraca analitik, food processor, cabinet drier, loyang dan wajan pemasak, gelas ukur dan termometer. Peralatan yang digunakan untuk analisis antara lain spektrofotometer UV-Vis, texture analyzer, pipet mohr dan peralatan lain yang digunakan untuk analisis proksimat, dan analisis karakteristik kimia.

\section{Metode}

\section{Proses pengolahan nori}

Proses pengolahan nori rumput laut $U$. lactuca dan E. cottonii sedikit berbeda dengan pengolahan nori komersial pada umumnya yang hanya menggunakan satu jenis rumput laut yaitu Phorpyra sp. Pada penelitian ini untuk memperoleh nori yang berkualitas, dilakukan dengan mencampur dua jenis rumput laut yaitu $U$. lactuca dan E. cottonii. Proses pengolahan nori pada penelitian ini berdasarkan modifikasi metode Teddy (2009), yang dimulai dengan tahap pembersihan dan perendaman untuk melunakkan jaringan rumput laut. Selanjutnya dilakukan penambahan air dengan perbandingan 1:1 (b/v) untuk rumput laut Ulva lactuca, yaitu 100 gram rumput laut ditambahkan $100 \mathrm{ml}$ air dan 1:10 (b/v) untuk Eucheuma cottonii, yaitu 100 gram Eucheuma cottonii ditambahkan air sebanyak $1000 \mathrm{ml}$. Adonan selanjutnya dimasak sampai menjadi bubur. Kedua jenis bubur rumput laut tersebut kemudian dicampur dengan perbandingan berat 1:3 (E. cottonii : U. lactuca) dan dibumbui dengan garam, bawang putih, dan lada sebanyak $0.3 \%$. Campuran bubur diratakan pada loyang dan dikeringkan pada suhu $50{ }^{\circ} \mathrm{C}$ selama 3 jam. Nori pada penelitian ini dibuat 2 jenis perlakuan, yaitu nori panggang yang diolesi dengan minyak kelapa pada suhu $100^{\circ} \mathrm{C}$ selama 3 menit (NT) dan nori yang tidak dipanggang (NM).

\section{Uji Karakteristik Fisik dan Sensori}

Pengujian sensori dilakukan terhadap atribut tekstur, warna, rasa, dan aroma dengan menggunakan uji rating hedonik. Panelis yang dibutuhkan sebanyak 30 panelis tidak terlatih. Skala yang digunakan pada uji rating hedonik ialah skala 1 sampai 7 yang terdiri dari: (1) sangat suka; (2) suka; (3) agak suka; (4) netral; (5) agak tidak suka; (6) tidak suka; (7) sangat tidak suka.

Uji fisik yang dilakukan berupa uji profil tekstur nori yang dianalisis menggunakan texture analyzer TA-XT2.

\section{Analisis Proksimat}

Penentuan kadar karbohidrat dilakukan secara by different. Analisis kadar air menggunakan metode oven, kadar abu metode pengabuan kering dan kadar lemak metode Soxhlet yang mengacu pada SNI 012891-1992. Sementara kadar protein dianalisis berdasarkan metode Kjeldahl (AOAC, 2006).

\section{Analisis Kapasitas Antioksidan}

Analisis kapasitas dilakukan berdasarkan metode Vijayabaskar dan Shiyamala (2012). Ekstrak sampel dengan formula terpilih sejumlah $3 \mathrm{ml}$ direaksikan dengan pereaksi $1 \mathrm{ml}$ DPPH 0,1mM kemudian ditempatkan dalam ruangan kedap cahaya selama 10 menit. Absorbansi larutan selanjutnya diukur menggunakan spektrofotometer UV pada panjang gelombang $517 \mathrm{~nm}$. 


\section{Analisis Total Fenol}

Analisis total fenol dilakukan berdasarkan metode Hodzic, Pasalic, Memisevic, Saletovic, \& Poljakovic (2009). Sampel direaksikan dengan pereaksi FolinCiocateu 50\% kemudian ditambahkan etanol $95 \%$, aquades dan $\mathrm{Na}_{2} \mathrm{CO}_{3} 5 \%$ kemudian ditempatkan dalam ruangan kedap cahaya selama satu jam. Absorbansi larutan selanjutnya diukur menggunakan spektrofotometer pada panjang gelombang $725 \mathrm{~nm}$.

\section{Analisis Serat Pangan}

Serat pangan dianalisis berdasarkan metode Asp, Johanson, Halimer, \& Siljestrom (1983). Sampel yang akan dianalisis terlebih dahulu diekstraksi lemaknya. Selanjutnya sampel dihidrolisis oleh termamyl ( $\alpha$ amilase tahan panas), protease, dan amiloglukosidase (AMG) untuk menghilangkan protein dan pati. Sampel kemudian ditambahi etanol $95 \%$ dan dibiarkan selama 60 menit untuk mengendapkan SDF (soluble dietary fiber). Sampel kemudian disaring dan residu dicuci dengan etanol $78 \%$, etanol $95 \%$, dan aseton. Kertas saring kemudian dikeringkan dan ditimbang beserta residunya. Hasil yang diperoleh dikoreksi terhadap kadar protein yang tidak dapat dicerna dan kadar abu dalam residu.

\section{Analisis Data}

Data yang diperoleh dianalisis secara statistik dengan Analysis of Varians (ANOVA), yang dilanjutkan dengan uji Duncan pada taraf nyata $5 \%$. Proses analisis data dilakukan menggunakan program SPSS.

\section{HASIL DAN BAHASAN}

\section{Proses Pengolahan Nori}

Penggunaan E. cottonii pada pembuatan nori sebagai pembentuk gel. Eucheuma cottonii merupakan rumput laut merah yang mengandung karaginan sebagai pembentuk gel dengan pigmen utama phycoerithin (Munier et al., 2014). Selama proses penyimpanan, pembersihan dan pemasakan terjadi degradasi warna sehingga bubur yang dihasilkan bewarna putih keruh. Adanya karaginan dari E. cottonii memberikan sifat gelling sehingga dapat membentuk lembaran tipis. U. lactuca merupakan rumput laut hijau yang mengandung klorofil yang tinggi sehingga dapat memberikan warna hijau gelap pada lembaran nori yang dihasilkan.

Proses penambahan garam, bubuk bawang putih dan lada pada pembuatan produk nori dilakukan untuk meningkatkan rasa dan aroma nori. Pemanggangan nori dilakukan untuk memperbaiki tekstur produk. Menurut McHugh (2003) pemanggangan nori dapat dilakukan pada suhu $120-140^{\circ} \mathrm{C}$ selama $40-60$ detik. Trial dan error untuk menentukan waktu pemanggangan dilakukan pada suhu $100^{\circ} \mathrm{C}$ sampai nori menunjukkan karakter crispy yaitu mempunyai tekstur yang kering, renyah dengan penampakan yang tidak gosong (nori masih terlihat hijau). Dalam penelitian ini, proses pemanggangan dilakukan pada suhu $100^{\circ} \mathrm{C}$ selama 3 menit. Waktu pemanggangan di atas 3 menit menghasilkan produk yang gosong. Pemanggangan nori menggunakan minyak kelapa yang dioleskan di atas permukaan nori. Penambahan minyak kelapa pada proses pemanggangan bertujuan untuk meningkatkan cita rasa produk nori. Akan tetapi perlu diperhatikan bahwa penambahan minyak kelapa yang berlebihan dapat meningkatkan kadar lemak produk nori dan menimbulkan ketengikan selama penyimpanan dalam jangka waktu tertentu. Perlu dilakukan penelitian lebih lanjut tentang masa simpan produk nori tersebut.

\section{Karakteristik Sensori Produk Nori}

Hasil uji organoleptik menunjukkan nori yang dipanggang (NT) lebih disukai dengan nilai organoleptik yaitu 2.32 untuk skor warna, 2.1 untuk skor aroma, 2.07 untuk rasa dan 2.03 untuk kerenyahan (Gambar 1). Proses pemanggangan dapat meningkatkan tingkat kerenyahan pada produk nori, sehingga lebih disukai. FAO (2006) menyatakan bahwa pemanggangan dapat meningkatkan kerenyahan nori. Hasil analisis statistik menunjukkan proses pemanggangan nori yang dibuat pada penelitian ini berpengaruh pada penerimaan konsumen secara signifikan pada taraf uji 5\%.

\section{Karakteristik Fisik Produk Nori}

Produk nori yang dipanggang (NT) mempunyai tingkat kekerasan yang lebih rendah (445 gf) dibandingkan produk tidak dipanggang (NM) (525 gf). Tingkat kekerasan produk pada uji tekstur dapat menunjukkan tingkat kerenyahan produk. Andarwulan et al., (2011) menyatakan bahwa tingkat kekerasan merupakan jumlah gaya yang dibutuhkan untuk mematahkan produk yang dinyatakan dalam satuan gram force ( $g f)$. Produk dengan tekstur yang renyah memiliki tingkat kekerasan yang lebih rendah (Andarwulan, Kusnandar, \& Herawati, 2011). Akan tetapi dibandingkan nori komersial, produk nori dari rumput laut $U$. lactuca dan $E$. cottonii mempunyai kekerasan yang lebih tinggi. Nori komersil mempunyai tingkat kekerasan 408 gf (MEXT, 2015). Nori yang 


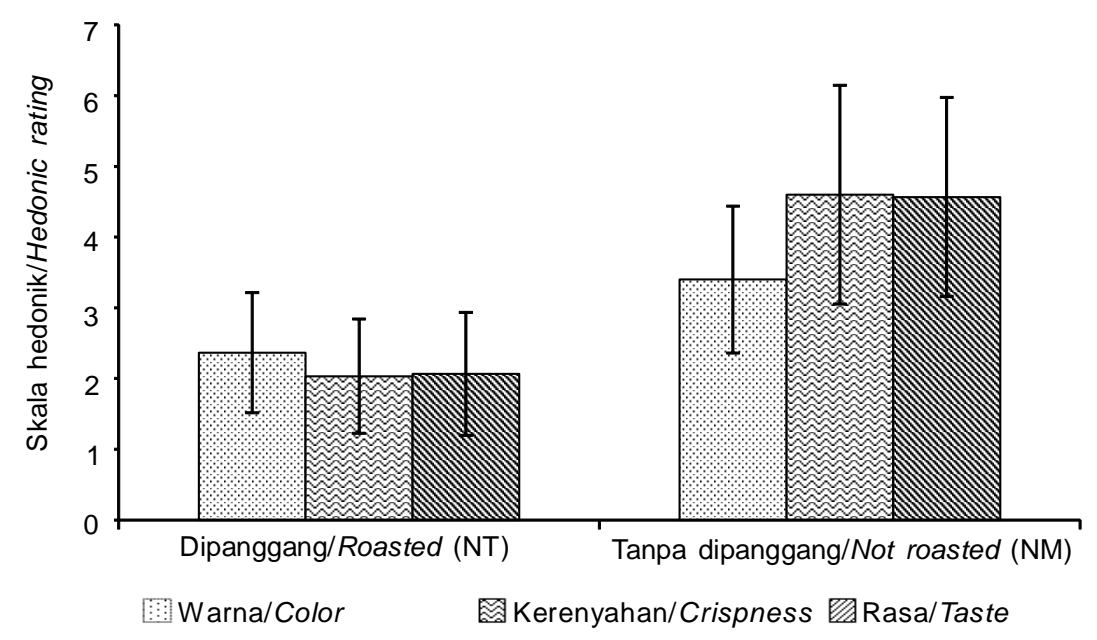

Gambar 1. Karakteristik sensori produk nori

Figure 1. Sensory characteristics of nori product

dipanggang (NT) mempunyai kadar air yang lebih rendah dibandingkan nori yang tidak dipanggang (NM) sehingga tekstur yang diperoleh lebih renyah. Pemanggangan mengakibatkan sebagian besar air keluar dari bahan pangan dalam bentuk uap air. Uap air yang keluar dari bahan pangan membentuk gelembung udara yang kemudian pecah membentuk pori-pori pada permukaan produk (Kawas \& Moreira 2001). Cofradez et al. (2000) menyatakan kandungan serat pada produk pangan dapat meningkatkan kekerasan produk. Produk nori dari bahan baku $U$. lactuca dan E. cottoniimengandung total serat pangan yang lebih tinggi dibandingkan nori komersial yang terbuat dari Phorphyra sp.

\section{Karakteristik Proksimat Produk Nori}

Hasil analisis proksimat produk nori yang dipanggang (NT) dan nori yang tidak dipanggang (NM) dibandingkan dengan nori komersial yang diacu pada standar produk nori di Jepang (NK) (MEXT, 2015) disajikan pada Tabel 1.

Berdasarkan Tabel 1 terlihat kandungan proksimat produk nori berbeda nyata pada taraf $5 \%$. Perbedaan

Tabel 1. Karakteristik proksimat produk nori

Table 1. Proximate characteristics of nori

\begin{tabular}{lrrr}
\hline \multicolumn{1}{c}{ Parameter/Parameters } & \multicolumn{1}{c}{$\mathbf{N T}^{\star *}$} & \multicolumn{1}{c}{$\mathbf{N M}^{\star *}$} & \multicolumn{1}{c}{$\mathbf{N K}^{\boldsymbol{}}$} \\
\hline Kadar air/Moisture (\%) & $6.39 \pm 0.01^{\mathrm{b}}$ & $9.85 \pm 0.01^{\mathrm{c}}$ & $4.47 \pm 0.00^{\mathrm{a}}$ \\
Kadar abu/Ash (\%) & $8.86 \pm 0.01^{\mathrm{b}}$ & $8.83 \pm 0.01^{\mathrm{a}}$ & $8.97 \pm 0.00^{\mathrm{c}}$ \\
Kadar lemak/Fat (\%) & $4.11 \pm 0.01^{\mathrm{b}}$ & $0.26 \pm 0.01^{\mathrm{a}}$ & $4.76 \pm 0.01^{\mathrm{c}}$ \\
Kadar protein/Protein (\%) & $18.22 \pm 0.01^{\mathrm{a}}$ & $18.84 \pm 0.01^{\mathrm{b}}$ & $40.00 \pm 0.01^{\mathrm{c}}$ \\
Karbohidrat/Carbohydrate (\%) & $62.43 \pm 0.01^{\mathrm{b}}$ & $62.31 \pm 0.01^{\mathrm{a}}$ & $41.80 \pm 0.01^{\mathrm{c}}$ \\
\hline
\end{tabular}

* MEXT (2015)

${ }^{*} \mathrm{NT}$ = Nori panggang/Roasted nori

${ }^{*} \mathrm{NM}=$ Nori yang tidak dipanggang/Unroasted nori

${ }^{*} \mathrm{NK}=$ Nori komersial/Commercial nori (MEXT, 2015)

Nilai $a, b$ pada baris yang sama menunjukkan perbedaan nyata secara statistic pada taraf $5 \% /$ The values of $a, b$ in the same row show statistically significant differences at the $5 \%$ 
Tabel 2. Karakteristik proksimat rumput laut bahan baku yang digunakan Table 2. Proximate characteristics of the seaweeds raw material used

\begin{tabular}{lrcc}
\hline \multicolumn{1}{c}{ Parameter/Parameters } & Ulva lactuca & Euchema cottonii & Porphyra $p^{*}$ \\
\hline Kadar air/Moisture (\%) & $7.43 \pm 0.02$ & $14.87 \pm 0.04$ & NA \\
Kadar abu/Ash (\%) & $16.33 \pm 0.01$ & $16.43 \pm 0.02$ & 21.3 \\
Kadar lemak/Fat (\%) & $0.36 \pm 0.01$ & $0.64 \pm 0.01$ & 2.8 \\
Kadar protein/Protein (\%) & $10.23 \pm 0.04$ & $15.84 \pm 0.07$ & 33.2 \\
Karbohidrat/Carbohydrate (\%) & $65.66 \pm 0.02$ & $52.11 \pm 0.01$ & 37.0 \\
\hline
\end{tabular}

*Data berdasarkan literature Taboada et al. (2012)/Based on literature Taboada et al. (2012)

kadar proksimat produk nori dipengaruhi oleh proses pembuatan nori dan jenis rumput laut yang digunakan. Kadar proksimat bahan baku rumput laut disajikan pada Tabel 2.

Berdasarkan Tabel 2, terlihat bahwa kadar proksimat bahan baku rumput laut berbeda antara ketiga jenis rumput laut. Perbedaan kadar proksimat bahan baku rumput laut sangat dipengaruhi oleh berbagai faktor. Faktor tersebut terdiri dari lingkungan laut, umur panen, penanganan pasca panen dan musim (Dawczynski, Schubert, \& Jahreis, 2006; Mabeau \& Fleurence, 1993; Ortiz, Bozzo, Navarrete, Osorio, \& Rios, 2006; Taboada, Millan \& Miguez, 2012).

Pemanggangan nori berpengaruh terhadap hasil proksimat produk nori yaitu terutama terhadap kadar air dan kadar lemak. Pemanggangan mengakibatkan sebagian air bebas keluar dan menguap ke lingkungan sehingga terjadi penurunan kadar air. Kadar air produk nori yang rendah berpengaruh terhadap tekstur kerenyahan nori. Disamping itu, penurunan kadar air produk diharapkan dapat memperpanjang umur simpan dengan mencegah pertumbuhan kapang dan menghambat reaksi kimia yang berlangsung karena ketersediaan air bebas (Kusnandar, 2010).

Perbedaan kadar abu produk nori dipengaruhi oleh perbedaan jenis rumput laut dan bahan tambahan pangan yang digunakan. Kandungan mineral dalam bahan baku menjadi salah satu penentu kadar abu dalam produk. Phorphyra sp. sebagai bahan baku pembuatan nori komersial mempunyai kadar abu sebesar $21,30 \%$ dengan mineral utama natrium (3627mg/100g bk) dan kalium (3500mg/100g bk) (Taboada et al. 2012). Kadar abu rumput laut $U$. lactuca dan $E$. cottonii yang digunakan lebih rendah dibandingkan Phorphyra sp. Kandungan mineral utama dalam rumput laut $U$. lactuca berasal dari magnesium dan kalsium dengan jumlah masing masing $3891 \mathrm{mg}$ dan $2720 \mathrm{mg}$ dalam $100 \mathrm{~g}$ bahan (Yaich et al., 2011).
Perbedaan kandungan protein nori dari campuran rumput laut $U$. lactuca dan $E$. cottonii dengan nori komersial juga sangat dipengaruhi oleh perbedaan kandungan protein bahan baku rumput laut, di mana rumput laut Phorphyra sp. sebagai bahan baku nori komersial mempunyai kadar protein yang tinggi.

Peningkatan kandungan lemak pada produk nori yang dipanggang (NT) disebabkan oleh penambahan minyak kelapa pada saat proses pemanggangan. Selama proses pemanggangan sebagian besar air berdifusi ke luar dari bahan pangan dalam bentuk uap air dan minyak berdifusi masuk ke dalam bahan pangan. Hal tersebut menyebabkan kandungan air produk menurun dan terjadi peningkatan kandungan lemak produk (Sugiyono \& Muchtadi, 2013). Phorphyra sp. mengandung kadar lemak yang lebih besar dibandingkan kedua jenis rumput laut yang digunakan yaitu 2,80\% (Taboada et al., 2012).

\section{Kandungan Serat Pangan Produk Nori}

Produk nori yang dihasilkan pada penelitian mengandung serat dalam jumlah tinggi $(36,76 \%)$ dibandingkan nori komersial. Nori komersia berdasarkan Taboada (2012) mengandung serat $21,3 \%$. Kandungan serat pangan tidak larut (SDF) produk nori hasil penelitian sebesar $19,12 \%$ dan serat pangan larut (IDF) sebesar 17,64\%, serta serat pangan total sebesar 36,76\%. Berdasarkan kandungan serat pangan terlihat bahwa nori yang dihasilkan mempunyai jumlah SDF dan IDF yang tidak terlalu berbeda sehingga produk ini berpotensi sebagai sumber serat pangan yang ideal.

Perbedaan kandungan serat antara nori hasil penelitian dengan nori komersial disebabkan oleh kandungan serat dalam bahan baku rumput laut. Kandungan serat pada Phorphyra sp. sebesar 21,3\% (Taboada et al., 2012). U. lactuca sebagai bahan utama yang digunakan dalam penelitian ini mengandung serat sebesar 59,6\% (Yaich et al., 2011). 
Tabel 4. Kapasitas antioksidan produk nori

Table 4. Antioxidant capacity of nori

\begin{tabular}{cc}
\hline Jenis Nori/Type of nori & Kapasitas antioksidan/Antioxidant capacity (\%) \\
\hline $\mathrm{NT}^{* *}$ & $41.53 \pm 0.24^{\mathrm{a}}$ \\
$\mathrm{NM}^{* *}$ & $43.01 \pm 0.01^{\mathrm{b}}$ \\
$\mathrm{NK}^{*}$ & $51.00 \pm 0.06^{\mathrm{c}}$ \\
\hline
\end{tabular}

* MEXT (2015)

${ }^{* *} \mathrm{NT}=$ Nori panggang/Roasted nori

${ }^{* *} \mathrm{NM}=$ Nori yang tidak dipanggang/Unroasted nori

${ }^{* *} \mathrm{NK}=$ Nori komersial/Commercial nori (MEXT, 2015)

Nilai $a, b$ menunjukkan perbedaan nyata secara statistic pada taraf $5 \% /$ The values of $a, b$ show statistically significant differences at the 5\%

Kapasitas Antioksidan dan Total Fenol Produk Nori

Kapasitas antioksidan produk nori diukur dengan metode DPPH. Hasil penelitian menunjukkan nori dari campuran rumput laut $U$. lactuca dan $E$. cottonii mempunyai kapasitas antioksidan yang berbeda nyata dibandingkan nori komersial. Nori yang dipanggang (NT) mempunyai kapasitas antioksidan yang berbeda nyata dibandingkan produk nori yang tidak dipanggang (NM). Produk nori komersial (NK) mempunyai kapasitas antioksidan sebesar 51\% (Ismail \& Hong, 2002)

Perbedaan kapasitas antioksidan produk nori dipengaruhi oleh komponen bioaktif yang terkandung dalam suatu produk pangan, seperti komponen fenolik.
Zakaria, Nurrahman, Prangdimurti \& Tejasari (2003) menyatakan bahwa kandungan senyawa fenolik mempengaruhi kapasitas antioksidan produk. Selain itu, komponen bioaktif lain yang terkandung dalam rumput laut sebagai bahan baku nori juga mempengaruhi aktivitas antioksidan produk nori. Rumput laut mengandung sejumlah komponen bioaktif yang mempunyai aktivitas antioksidan (Gupta \& Ghannam, 2011; Pangestuti \& Kim, 2011). Stabilitas antioksidan juga dipengaruhi oleh suhu. Sebagaimana diketahui pada proses pembuatan nori menggunakan proses pemasakan dengan suhu tinggi sehingga senyawa antioksidan menjadi kurang stabil. Proses pemasakan yang melibatkan panas dapat mengurangi kandungan antioksidan dalam suatu bahan akibat terjadinya degradasi kimia dan fisik (Aisyah,

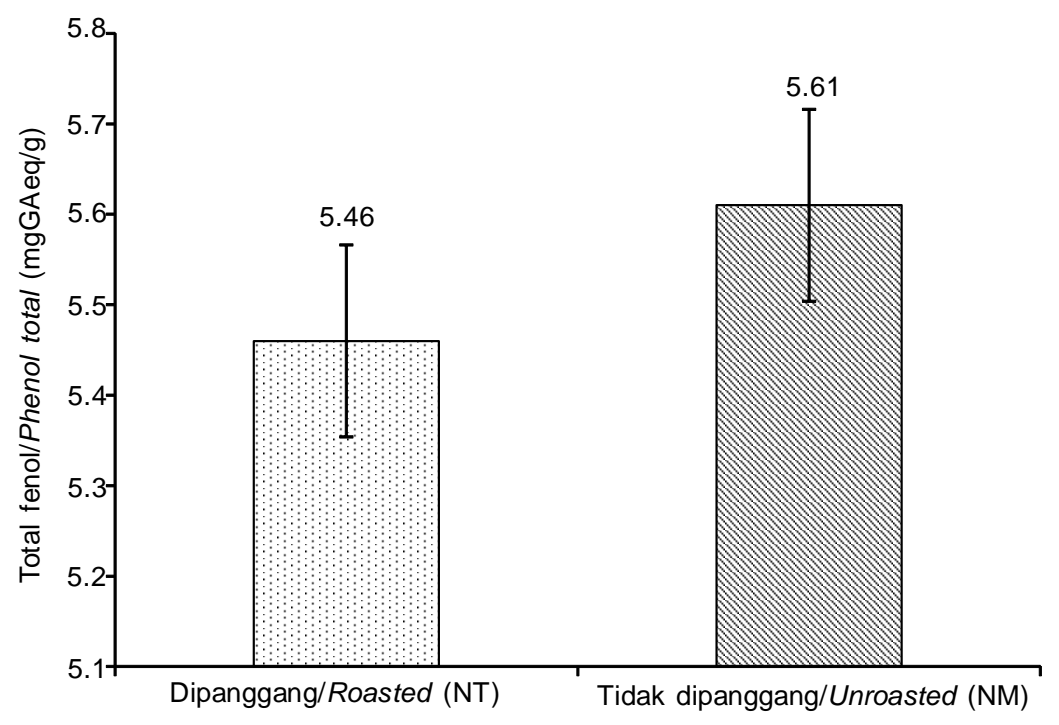

Gambar 2. Total fenol produk nori

Figure 2. Total phenol of nori 
Rasdiansyah, \& Muhaimin, 2014). Proses pemanggangan menyebabkan penurunan kapasitas antioksidan pada produk nori yang dipanggang.

Total fenol produk nori disajikan pada Gambar 2. Total fenol produk dipengaruhi oleh kandungan senyawa fenolik pada bahan baku rumput laut. Kandungan total fenol pada masing masing rumput laut ialah $U$. lactuca $9.61 \mathrm{mgGAeq} / \mathrm{g}, 1.88 \mathrm{mgGAeq} /$ g pada E. cottonii, dan $18.43 \mathrm{mgGAeq} / \mathrm{g}$. pada Phorphyra sp. (Maria et al., 2008). Proses pemanggangan juga dapat menurunkan kadar total fenol produk nori. Hal ini karena sebagian senyawa phenolik dapat terurai oleh suhu. Aisyah et al., (2014) menyatakan bahwa proses pemanasan dapat mengubah struktur fenolik dari senyawa fenol.

\section{KESIMPULAN}

Campuran rumput laut E. cottonii dan U. lactuca dapat diolah untuk menghasilkan produk nori yang berkualitas. Hasil analisis mutu fisik, sensori dan proksimat nori dari campuran rumput laut $E$. cottonii dan U. lactuca yang dipanggang berbeda nyata secara statistik dengan nori yang tidak dipanggang ataupun nori komersial. Kandungan serat nori dari campuran rumput laut $E$. cottonii dan $U$. lactuca lebih tinggi dibandingkan nori komersial, akan tetapi kandungan total fenol dan kapasitas antioksidan lebih rendah. Pemanggangan nori menghasilkan produk yang lebih renyah namun mengalami penurunan nilai total fenol dan kapasitas antioksidan. Secara keseluruhan berdasarkan karakteristik fisik, kimia dan sensori produk nori dari campuran rumput laut $E$. cottonii dan U. lactuca layak untuk dikembangkan lebih lanjut.

\section{UCAPAN TERIMA KASIH.}

Ucapan terima kasih disampaikan kepada Kementrian Riset dan Teknologi melalui Lembaga Penelitian dan Pengabdian Masyarakat Institut Pertanian Bogor yang telah mendanai penelitian ini melalui program Penelitian Unggulan Peguruan Tinggi.

\section{DAFTAR PUSTAKA}

Aisyah, Y., Rasdiansyah., \& Muhaimin. (2014). Pengaruh pemanasan terhadap aktivitas antioksidan pada beberapa jenis sayuran. Jurnal Teknologi dan Industri Pertanian Indonesia, 6(2), 28-32.

Andarwulan, N., Kusnandar, F., \& Herawati, D. (2011). Analisis Pangan. Jakarta (ID): Dian Rakyat.

[AOAC] Association of Official Analytical Chemist. (2006). Official Method of Analysis of Official Analytical of Chemist. The Association of Official Analytical Chemist, Inc. Arlington.
Asp, N. G., Johanson, C. G., Halimer, H., \& Siljestrom. (1983). Rapid enzymatic assay of insoluble and soluble dietary fibre. J Agri Food Chem., 31,476-482.

Badan Pusat Statistik. 2016. Impor Komoditas Dinamis. $\quad$ https://www.bps.go.id/all new template.php [diakses 07 Apr 2016]

Cofrades, S., Guerra, Carballo, J., Martin, F., \& Colmenero, J. (2000). Plasma protein and soy fiber content effect on bologna sausage properties as influenced by fat level. Food Chemistry and Toxicology, 65, 281-287.

Dawczynski, C., Schubert, R., \& Jahreis, G. (2006). Amino acids, fatty acids, and dietary fibre in edible seaweed products. Journal Food Chemestry, 103, 891-899.

Direktorat Jenderal Perikanan Budidaya K K P. (2014). Laporan Tahunan Direktorat Produksi Tahun 2013. Jakarta (ID) : KementrianKelautan dan Perikanan.

Food and Agriculture Organization. (FAO). (2006). Seaweeds used as human food [internet]. Diakses tanggal: 1 Februari 2017. Tersedia pada: http:// www.fao.org.

Fayaz, M., Namitha, K., Murthy, C., Swamy, M., Sarada, R., Khanam, S., Subbarao, P. V, \& Ravishankar, G. A. (2005). Chemical composition, iron bioavaibility, and antioxidant activity of Kappahycus alvarezzi. J Agric Food Chem., 53, 792-797.

Gupta, S., \& Ghannam, N. A. (2011). Bioactive potential and possible health effects of edible brown seaweeds. Trends in Food Sci and Technol., 20, 112.

Hodzic, Z., Pasalic, A., Memisevic, M., Saletovic M., \& Poljakovic, M. (2009). The influence of total phenol content on antioxidant capacity in the whole grain extracts. Eur J of Sci Res., 28(3), 471-477.

Hwang, E. S., Ki ,K. N., \& Chung, H. Y. (2013). Proximate composition, amino acid, mineral and heavy metal content of dried laver. Journal Prev. Nutr. Food Sci., 18. :139-144.

Ismail, A., \& Hong, T.S. (2002). Antioxidant activity of selected commercial seaweeds. Mal J Nutr., 8(2), 167-177.

Kawas, M.L., \& Moreira, R.G. (2001). Effect of degree of starch gelatinization on quality attributes of fried tortilla chips. Jurnal of Food Science, 66 (2) , 300-306.

Kusnandar, F. (2010). Kimia Pangan Komponen Makro. Jakarta (ID) : Dian Rakyat

Maria, N., Garcia-Casal, Ramirez, J., Leets, I., Pereira, A.C., \& Quiroga, M.F,. (2008). Antioxidant capacity, polyphenol content and iron bioavailability from algae (Ulva Sp., Sargassum Sp. And Porphyra Sp.) in human subjects. J Food Chem., 101,79-85.

Mabeau, S., \& Fleurence, J., (1993). Seaweed in food products: biochemical and nutritional aspects. Trends Food Sci Technol., 4,103-107.

Ministry of Education, Culture, sports, Science and Technology. (MEXT). (2015). Standard Tables of Food Composition in Japan Seventh Revised Edition. Tokyo (JPN) 
Mchugh, D. J. (2003). A guide to the seaweed industry. Rome. Food and Agriculture Organization of the United Nations.

Munier, M., Jubeau, S., Wijaya, A., Morancais, M., Dumay, J., Marchal, L., Jaouen, P.,\& Fleurence, J. (2014). Physicochemical factors affecting the stability of two pigments: R-phycoerythrin of grateloupia turuturu and B-phycoerythrin of Porphyridium cruentum. J Food Chem., 150, 400-407.

Ortiz, J., Bozzo, C., Navarrete, E., \& Osorio, A., Rios, A. (2006) . Dietary fiber, amino acid, fatty acid and tocopherol contents of the edible seaweeds U/va Lactuta and Durvillaea antarctica. J Food Che, 99, 98-104.

Palupi, N. S., Sitorus, S. R., \& Kusnandar, F. (2015). Perubahan alergenitas protein kacang kedelai dan kacang bogor akibat pengolahan dengan panas. $J$ Teknol dan Industri Pangan, 26, 222-231.

Pangestuti, R., \& Kim, S. K. (2011). Biological activities and health benefit effects of Natural pigments derived from marine algae. J Functl Foods, 3, 255-266.

(SNI). Standar Nasional Indonesia. (2006). SNI 01-23462006. Petunjuk Pengujian Organoleptik dan atau Sensori. Badan Standar Nasional Indonesia, Jakarta.

(SNI). Standar Nasional Indonesia. (1992). SNI 01-28911992. Cara Uji Makanan dan Minuman. Badan Standardisasi Nasional Indonesia. Jakarta.
Sugiyono \& Muchtadi, T. R. (2013). Prinsip Proses dan Teknologi Pangan. Bogor (ID): Alfabeta.

Taboada, M. C., Millan, R., \& Miguez, M. I. (2013). Nutritional value of the marine algae wakame (Undaria Pinnatifida) and nori (Porphhyra Purpurea) as food suplements. J. Appl Phycol., 25, 1271-1276.

Teddy, S. (2009). Pembuatan Nori Secara Tradisional dari Rumput Laut Jenis Glacilaria sp. [Skripsi]. Bogor. (ID): Institut Pertanian Bogor.

Vijayabaskar, P., \& Shiyamala, V. (2012). Antioxidant properties of seaweed polyphenol from turbinaria ornata (Turner) J. Agardh, 1848. Asian Pacific Journal of Tropical Biomedicine, 90-98.

Yaich, H., Garna, H., Besbes, S., Paquot, M., Blecker, C., \& Attia, H. (2011). Chemical composition and functional properties of UlvalLactuca in Tunisia. $J$ FoodChem, 128, 895-901.

Zakaria, F. R., Nurrahman, Prangdimurti, E., \& Tejasari. (2003). Antioxidant and immunoenhancement activities of ginger (Zingiber officinale Roscoe) extracts and compounds in vitro and in vivo mouse and human system. Nutraceuticals and Food. 8 (1): 96-104.

Zakaria, F. R. (2015). Pangan Nabati, Utuh dan Fungsional sebagai Penyusun Diet Sehat. Bogor. (ID). Orasi IImiah Guru Besar Institut Pertanian Bogor. 